\title{
The Power of Visual Culture and the Fragility of the Text
}

\author{
Peter M. Phillips
}

In his reflections on Bible engagement in medieval Europe, Dr Eyal Poleg focuses on the centrality of the mediated bible: ${ }^{1}$

Taken at face value, the dietary laws of Leviticus, the love lore of the Song of Songs, or the visions of Revelation had little to do with the values of Christian (or Jewish) medieval culture. Keeping these archaic narratives relevant and alive was thus a necessity. This led to a high degree of creativity in expounding and exploring the Bible, making biblical mediation a dynamic part of society, ever changing and bringing new texts, tunes, objects, and monuments into its ambit. The Bible was made all things to all people, in a process that was often veiled and hidden.

Poleg focuses on liturgical processions, sermons and on the Bible as a talisman, but he could have looked as well at songs, poetry, art, mystery plays, festivals and rites. Medieval society was centered around the Bible as a sourcebook for the European imaginarium ${ }^{2}$, forming the basis for civic administration, law codes, and cultural expression of all kinds. The wealth of the Church and its social standing within the aristocracy, of course, meant that this was not an open process of cultural influence but one of cultural domination, the product of the Church's hold on wealth and influence throughout Christian Europe. In an age of limited literacy, Poleg shows that "the majority of men and women experienced the Bible through a carefully structured array of rituals and images, sermons and chants." ${ }^{3}$ Indeed, one could argue that this audio-visual, aesthetic experience of the Bible has dominated Bible engagement over the last two thousand years. In our own day, the material text of the Bible is also being

1 Poleg, Eyal, Approaching the Bible in Medieval England, Uk: Manchester University Press, 2013, 2.

2 Charles Taylor refers to the social imaginary as a gathering together of the set of values, laws, conventions and symbols common to a social group. See Charles Taylor, "Modern Social Imaginaries", Public Culture 14, Number 1, Winter 2002, 91-124.

3 Poleg, Approaching the Bible, 1. 
mediated through apps and websites, through digitised manuscripts and all manners of digital expressions. We are witnesses of the ongoing mediation of the Biblical text now through contemporary expressions of visual and material culture.

The various products or artefacts of both medieval and contemporary cultural influence work together to amplify the individual impact of any one artefact. The sheer weight of biblical material across all the modes of artistic and practical expression in the medieval period witnesses to the power and dominance of the Church and creates a powerful aesthetic experience - that Christianity is normative within the European imaginarium. Moreover, time and again, medieval examples show oral, visual, textual and material means of dissemination converging together to multiply their effect: liturgy and preaching performed at the same time, sharing the same space and actors; visual imagery reflecting dramatic reenactments; exegetes and preachers, often the same people, mixing interpretation and homiletics; and literary narratives employing biblical and liturgical tags interchangeably.

Biblical texts, of course, themselves tend to speak in visual language, in metaphors and similes, in arresting visual stories, in parables and narratives - inviting the reader to see the events being described, to come and see Jesus, to watch the events being narrated. So, Jo-Ann Brant has skillfully explored the dramatic structures within John's Gospel, complete with prelude and epilogue, with scenes made up of Jesus as protagonist, a potential disciple as antagonist, and a chorus of disciples or local spectators. ${ }^{4}$ At conferences of the Society of Biblical Literature, as at other gatherings of the Biblical guild, there are whole programmes exploring the Bible as a mediated and performed text.

The Bible as a whole, as well as its constituent texts, have always been part of visual culture: as stone tablets, or scrolls, or codices; as texts scrawled in graffiti or painted on murals; as mosaics embedded in villas or texts on walls. With few people able to engage with texts through reading (although perhaps significantly more than some have argued ${ }^{5}$ ), Bible engagement had to be facilitated in any way it could - usually through the mediated Bible. The advent of moveable-type print shifted the emphasis towards greater precision and accuracy and perhaps, as we shall see, created a passing domination of text over image, of precision over aesthetics. But there is a rapid shift away from such dominance. In today's digital world, the Bible remains a mediated text. Despite

4 Brant, Jo-Ann, Dialogue and Drama: Elements of Greek Tragedy in the Fourth Gospel, UsA: Hendrickson, 2004.

5 See, for example, Wright, Brian J., "Ancient Literacy in New Testament Research: Incorporating a few more line of enquiry", Trinity Journal 36, 2015, 161-189. 
historically superb literacy rates, the Bible is still a text engaged through visual and material culture, through performance and exhibition as well as through devotion and interpretation. So, we note the importance of Katie Edwards' edited collection exploring the role of the arts and media in contemporary biblical literacy ${ }^{6}$, and of the work of all those who bridge the gap between culture and the Bible.

Today's exploration of the Bible through digital media is therefore a contemporary spin on a much older relationship between visual technology and the Biblical text/Biblical tech. In his exploration of Christianity and the Culture Machine, Vincent Rocchio picks up the shift from the visual/aesthetic gestalt within medieval experience of Christian practice, to the text immanence dominated by clerical authority throughout modernity/the Enlightenment. He argues strongly that both Vatican II and the contemporary papacy of Pope Francis signal, in different but consonant ways, a powerful shift back to the gestalt experience of the visual - that moment of recognition when the visual reveals something profound about wider culture. Rocchio extends his argument not so much through a discussion of the papacy but through the shifting paradigms within contemporary cinematography. Often, the tropes of midtwentieth century Bible epics followed the lines of text/clerical dominance, but these have gradually shifted towards a more diverse exploration of biblical engagement through visual experience/gestalt. ${ }^{7}$

In his introduction, Rocchio explores A Charlie Brown Christmas (CBS, 1965), which includes a fifty- second recitation from Luke 2:8-14 from the King James Bible. ${ }^{8}$ This section of the programme was highly controversial at the time in that it stripped away all of the usual accompaniment to the Bible on screen and instead gave the words to a contemporary child, without backing track, additional visuals, or humour. Instead, the audience is invited "to imagine however briefly - the sacred in a post-sacred world, without resorting to a return to the past. Rather, in a message similar to Pope Francis, the narrative suggests that attending to 'the least of these' can accomplish transcendence."

Mediation of cultural artefacts through visuality is at the very centre of digital culture. Contemporary society seems to have a love affair with all things visual: all manner of flashing screens; the tiresome wit of animated gifs; the vocabulary and syntax of the emoji; the ubiquity of video. David Morgan, of course, spends most of his two recent books (The Sacred Gaze and The

6 Edwards, Katie, Rethinking Biblical Literacy, uk: Bloomsbury, 2015.

7 Rocchio, Vincent, Christianity and the Culture Machine, Eugene: Cascade Books, 2016.

8 Rocchio, Vincent, 7-15.

9 Rocchio, Vincent, 15. 
Embodied Eye) arguing strongly that 'seeing' performs religious action, or 'seeing' constructs or enacts a situation called sacred. ${ }^{10}$ In other words, our gaze enables the construction of the sacred by investing attention and time on a given artefact or experience. We make the object the center of our attention and so sacralise it. Or as Rocchio would put it: "art and media can bring us into contact with the experience of revelation and the transcendent itself." 11

In both books, Morgan seeks to define visual culture as both the act of seeing and the communicative sociology of that act: ${ }^{12}$

Visual culture refers to all the means of constructing life-worlds - attitudes, conceptual schemata, emotion, social dynamics, institutions. In addition to images, it is ways of seeing as well as the practices that deploy images. The study of visual culture is not just about pictures, but also powerful forms of embodiment, that is, the gendered, sexual, racial, ethnic, sensuous characteristics of perception and feeling that constitute primary forms of organizing human values.

In a world of image, advertising and the apparent dominance of the visual over the textual, it is important to realize that visual culture is, in Thomas Mitchell's words, "the visual construction of the social, not just the social construction of the visual". ${ }^{13}$ Indeed, it is not that visual culture is a social construct but that our very social arrangements take the form they do because we are seeing animals. ${ }^{14}$ We map our world by visual construals - quite literally using maps based on Mercator's projection or Peeters', knowing that neither fully expresses geographical reality. In the information age, we increasingly seek to grapple with unfathomable amounts of data through visualization, modeling and infographics.

But none of this is new. Contemporary culture is in fact no more fixated with the visual than any other culture, as Mitchell points out, ours has been a visual culture since God looked down upon creation and saw that it was good (the repeated refrain in Gen 1:4, 10, 12, 18, 21, 25, 31) - or perhaps even when God

10 Morgan, David, The Embodied Eye, Religious Visual Culture and the Social Life of Feeling, USA: University of California Press, 2012, xiii; Morgan, David, The Sacred Gaze: Religious Visual Culture in Theory and Practice, USA: University of California Press, 2005.

11 Rocchio, Vincent, Culture Machine, 15.

12 Morgan, David, The Embodied Eye, 31.

13 Mitchell, W.J.T., "Showing seeing: a critique of visual culture", Journal of Visual Culture, Vol. 1(2), 2002, $1 \quad 166$.

14 Mitchell, W.J.T.,"Showing seeing”, 171. 
chose to separate the light from the darkness (Gen 1:4) $)^{15}$ In other words, we are not moving into a visual age: we never left the visual age. When Derrida famously declared "il n'y a pas de hors-texte" - 'there is no outside-text' - perhaps he should have said something like "il n'y a rien en dehors de l'image", 16 (although, as most of us postmodern deconstructors were shown by Roland Barthes, the Derridean text might include anything which conveys meaning, which is really anything you want it to be).

Increasingly, though, in a world which celebrates the subjective turn, or what Mitchell calls the "pictorial turn", ${ }^{17}$ while we objectify the act of seeing into a reification of culture itself, we cannot but see that culture turning its gaze upon us - like the piercing and apparently critical gaze of Derrida's cat in L'animal que donc je suis. ${ }^{18}$ Mitchell reminds us of the work of Lacan, Derrida and Bal, in which they analyze the power of the image to challenge me, the spectator:

that images look back at us ... the eidolon talks back to us, gives orders, demands sacrifices ... why vision is never a one way street ... why the question to ask about images in not just what they mean, or what they do? But what is the secret of their vitality - and what do they want?19

The turn towards images ... is a turn towards the acceptance of the proposition that images can speak and tell as much as they can show and represent. $^{20}$

We need to remember that we cannot necessarily split off visual culture from textual culture, visual representations from textual representations. Textual representations themselves are visual artefacts - ink marking difference on paper, signifying meaning, screens full of programmed pixels. We need to "come

15 Mitchell, W.J.T.,"Showing seeing”, 174.

16 Derrida, Jacques, Of Grammatology, trans. Spivak, Gayatri Chakravorty, UsA: The John Hopkins University. Press, 1976, 158-159.

17 Grønstad, Asbjørn, Vågnes, Øyvind, "What do pictures want? An interview with W.J.T. Mitchell" Images: Journal for Visual Studies, accessed 12.7.2016: <http://www.visual-stud ies.com/interviews/mitchell.html>.

18 Derrida, Jacques, Le Animal que donc je suis, Paris: Éditions Galilée, 2006.

19 Mitchell, W.J.T., "Showing seeing", 176; to be fair, Mitchell focuses on Lacan's classic concept of the cat's cradle encompassing the screen, but there are links to arguments in Derrida's L'animal que donc je suis where the observed cat seems to observe and critique the author's nakedness.

20 Purgar, Krešimir, "Visual Studies and the Pictorial Turn: Twenty Years Later", Images No.2, 2014, accessed 12.7.2016: <http://www.visual-studies.com/images/no2/purgar.html>. 
to terms with reality in its multifaceted, multimodal, multimedia forms." ${ }^{21}$ At the same time, as Rocchio argues, the various methodological shifts in pedagogy, philosophy, and cultural practice mean that we no longer have a monolithic approach to the text of the Bible. Instead, different models are being explored through what he terms "trans-disciplinary" aesthetics. Rocchio points to three different engines for that change in semiotics, psychoanalysis and critical theory. ${ }^{22}$ Clearly, cultural exegesis has for a long time been moving down those trajectories, shifting away from the certainties of modernist interpretation and critique, to a much more nuanced understanding of both the potentialities and imperfections of our interpretations.

This paper seeks to ask what is happening when powerful, vibrant visuality engages an apparently fragile text - when the culture machine is let loose on the Bible. Is Rocchio correct in arguing that attention to the visual, to transdisciplinary aesthetics, will enable us to see more of the text, to see the text in new light? Or will the text be suborned by the visual, lost among the contemporary whorl of imagery? If text is as much about visual culture as anything else we see, if text itself is icon or eidolon or sign, does its expression within visual culture offer a re-representation, a re-packaging, a re-signification of the text to the reader? Indeed, such questions could be asked about the effect of digitizing the text - does the process of digitalization, the rendering of material texts into digital form, transform the audience's engagement with the Bible and with its manuscripts? Do we read Biblical texts the same on screen? Do we understand the paratextuality of digital forms?

Although we don't have the space here to grapple with some of these larger issues, we will explore the interaction between visual culture and the Bible through three brief examples: the Lindisfarne Gospels exhibition, the list of most retweeted bible verses of 2015, and Darren Arnofsky's Noah. The former allows us to explore the physical display of a material artefact; the second to explore social media engagement and the impact of visual additions to the text; the third to explore the culture machine at full power as the Bible is embraced by Hollywood. We will need to explore what happens, but also what models are developed to guide the audience in their aesthetic interpretation of the synthesis between the text and visual culture.

21 Purgar, Krešimir, "Visual Studies".

22 Rocchio,Vincent, Culture Machine, 17-25. 
In the Summer of 2013, the Lindisfarne Gospels were exhibited at Durham University. ${ }^{23}$ The Gospels are an exquisitely illustrated Anglo-Saxon manuscript of the four gospels created on Holy Island, Northumberland (also known as Lindisfarne) some 1300 years ago. The texts have a close relation with Durham: Lindisfarne is about 100 miles north of the city and the Gospels were carried there with the remains of St Cuthbert when the monks fled the island after sustained Viking raids in the ninth century. The Gospels remained at Durham until the Dissolution of the Monasteries under Henry viII and eventually became part of the British Library's collection of ancient manuscripts.

The Gospels were exhibited in Durham with a number of other biblical texts, including St Cuthbert's own copy of St John's Gospel (formerly known as the Stonyhurst Gospel), the earliest known surviving example of Western bookbinding. As part of the exhibition, you could see the Gospels themselves - open on different days on different pages - as well as several other artefacts of the Northern Celtic saints and Anglo-Saxon spirituality, all carefully laid out under glass, in carefully controlled atmospheric conditions. You could visit the gallery rooms and see how the gospels were made and excel in the craftsmanship of Eadfrith's textual work, Aethelwald's binding, and Billfrith's ornamentation ${ }^{24}$ (although the existing cover is a modern replica - the Vikings stole the original!). You could even engage in writing out your own version of the Gospels.

The Lindisfarne Gospels were and are an exquisite visual experience - a cultic artefact, a processional relic, symbolizing reverence for both the text it contains and the saint whom it commemorates. The text was used through its history as a liturgical focus for worship and as a community focus for Lindisfarne's monks and then for the Benedictine community at Durham. The Gospels are also a visual reminder of the wealth, power and artistic brilliance of 8th century Anglo-Saxon Northumbria. But, the text is written in Latin. Just as few modern readers can read its archaic text, it seems that even the monks of

23 <http://www.bbc.co.uk/news/uk-england-tyne-24329431>, accessed 10.4.19.

24 Eadfrith was the Bishop of Lindisfarne at the end of the seventh century and is believed to have illustrated the Gospels. Aethelwald and Billfrith were presumably members of the Lindisfarne community involved in binding the book and ornamenting the cover. For more information on the Gospels see <https:/www.bl.uk/collection-items/lindisfarnegospels $>$, accessed 10.4.19; and for more information on the exhibition, see $<$ https://www. dur.ac.uk/palace.green/whatson/details/?id=18081>, accessed 10.4.19. The British Library provides an online visualisation of the Gospels: <http://www.bl.uk/onlinegallery/ttp/ lindisfarne/accessible/introduction.html>, accessed 10.4.19. 
Lindisfarne seemed to have needed assistance. Written in the gaps between the beautiful Latin text is a tenth century Anglo-Saxon translation/gloss, in fact the earliest translation of the Gospels into an English language. The gloss was inserted onto the Gospels by Aldred, Provost of Chester-le-Street (ten miles north of Durham) sometime in the tenth century, perhaps as a pedagogical tool for his fellow monks or as a cultural statement on the increasing importance of English. Could this, perhaps, provide a hint that the Gospels were a working text, a cultural text as well as a visual artefact?

Robert Stanton's assertion is that the gloss is not pedagogical and that the text itself was not used in regular pedagogy within the community not least since the manuscript does not show multiple frequent usage. ${ }^{25}$ Its size and ornamentation suggest that its place is on the altar rather than the workbench. As such, the gloss, completed as part of an economic transaction, may well be more of a cultural process of glossing Latin texts into English that follows on from the practice of both Bede and Aldred in translating texts into the vernacular. In a way, it is a process of co-opting the Latin text into the support of English. Stanton goes on to argue that such texts were self-referential. Aldred goes to some lengths to ensure that the text is understood in the very context of tenth century Britain. When Mary is introduced, Aldred provides four glosses to explain Joseph's relationship with Mary prior to the birth - betrothed, entrusted, troth-plighted or pledged ("biwoedded", "beboden", "befeastnad", "betaht") - desperate to avoid any sense that Jesus was Joseph's natural child. In fact, contemporary Anglo-Saxon scholars can no longer see the specific differences between those four words. Later, in his gloss of Luke 6:22, Aldred seems to make a huge mistake. The Beatitude in Luke 6:22 warns that "men shall cast out your name as evil for the son of man's sake". Aldred glosses "evil" as "yfel / apoltre" (evil/apple-tree). He knows that "evil" is the correct gloss for "malum', but he also adds a gloss linked to the Latin word for "apple", "mãlum" (with a long "a") and gives "apple tree". Is Aldred being lax? Or is he being too clever - creating a literary link between evil and the fruit tree, the apple tree, in Genesis and the Fall, the source of all evil? Does he expect his reader to recognise the schoolboy error but to see the over-clever pun beneath? If so, this seems to be more of a self-aware cultural exercise than a pedagogical tool for Northumbrian monks.

The role of the Aldred's gloss perhaps was to remind his pupils or those reading from the manuscript that there is a beauty that goes beyond the visual.

25 This section draws on Stanton, Robert, The Culture of Translation in Anglo-Saxon England, Boydell and Brewer: 2002, 9-55 and on a public lecture given by Professor Eric Stanley on 3oth April 2013 . 
But, more likely, the gloss is part of a wider cultural assimilation of Insular manuscripts (compare the independent glossing of the Rushworth Gospels) into the increasingly confident world of Anglo-Saxon Britain. The visual splendour, Aldred knows, is dependent on the wonder of the words contained within it. But that splendor needs to be translated into Anglo-Saxon words for the new nation to align itself with the glory of its faded past. Aldred amends and resignifies the visual beauty because he sees something much more important in this text - the importance of the message it conveys, as well as the cultural opportunity to appropriate something of the past glory of the North to the service of the emergent Anglo-Saxon present.

In the terms of transactional aesthetics, what is happening here? In the present, none of the complexity about Aldred's gloss or the meaning of the original text surfaced in the exhibition. The Gospels were portrayed/exhibited as a visual, material artefact. The other activities around the exhibition pointed to this visuality and materiality. You could make your own Gospel but were never told about the contents of the Gospel. As a reader of ancient languages, I was able to gaze in wonder at the perfect script of the Gospel of John in red ink on white vellum. But for many visitors, the text was perhaps unintelligible, and no translations were provided. As such, the medium of interpretation focused wholly on the visual rather than the textual - the book became something to see rather than something read. Indeed, it might even be that in terms of critical theory and ideological criticism, the voice of the Gospels was silenced by the hegemony of secular humanism within contemporary academia - the actual words of the Gospel silenced in preference to the visual experience of a work of art. Instead, the exhibition focused on cultural and material issues about the Gospels to exclusion of the text's actual meaning. Such a focus was facilitated by the texts' otherness - the use of Latin, Greek and AngloSaxon - and so replicated only the visual/material importance of the text rather than its linguistic content that was largely ignored through the process. Is this an example of the image dominating the text? Of visual culture denying the place of text? Of materialism celebrating its own materiality in denying the presence of the other?

It goes without saying that there is a huge gap between the visual culture of late seventh century Northumberland and that of contemporary Western digital culture. The Lindisfarne Gospels' exhibition provided a visual expression of a text, but an exhibition which actually minimized the reading of the text, the deciphering of the words, counter to the artefact's own history. We now move to another contemporary exhibition - the use of the Bible in celebrity tweets, which include Bible references. What's the dynamic here between visual culture and the Biblical text? 


\section{Verses, RTs, Source Account}

$1 \quad$ Phil 1:3: "I thank my God every time I remember you." (33,476 RT @mainedcm)

21 Cor 13:13: “And now these three remain...” (13,365 RT @allybrooke)

3 Ps 16:11: "Walk on his path..." (11,474 RT @camerondallas) *altered text

4 Rom 8:18: "I consider that our present sufferings...” (10,755 RT @camerondallas)

$5 \quad$ Prov 27:2: "Let someone else praise you..." (10,206 RT @RealCoryMachado)

6 Jer 29:11: “For I know the plans I have for you...” (10,279 RT @ddlovato)

7 Jn 1:5: "The light shines in the darkness...” (7,308 RT @allybrooke)

8 Ps 120:1: "I call on the Lord in my distress..." (7,550 RT @MannyPacquiaoTR)

$9 \quad$ Col 3: (no verse specified!) (6,70o RT @siwon407)

10 Eph 4:32: “Be kind to one another...” (5,731 RT @TimTebow)

In his regular sharing of biblical data on the OpenBible website, Stephen Smith made available a list of the most retweeted Bible verses of 2015 given in Table $2.1 .^{26}$

The tweets originate from and reflect aspects of an interesting mix of different cultures. They are visual artefacts that appear in Twitter's livestreams as brief text messages always accompanied by the avatar representing the celebrity who has issued the tweet and sometimes with additional images appended to the tweet. They are permanent, though ephemeral artefacts - although every tweet remains part of the digital archive, the nature of Twitter livestream display means that they can be very ephemeral - passing through on the way to digital obscurity. Notification and listing protocols can allow tweets to "survive" longer in the public's awareness, as also happens with retweeting and commenting, but generally tweets fly by pretty quickly. They are digital artefacts and part of the ephemerata of digital culture, meant to be viewed on wearables, smartphones, tablets, laptops, or computers of any kind.

$26<$ https://www.openbible.info/blog/2015/12/the-bible-on-twitter-in-2015/>, accessed 10.4.19. 
The ephemeral nature of the tweet and its reliance on digital delivery means that each tweet competes to be seen - to be maximized for impact. As such, there are clear strategies for maximizing the visual impact to gain the required readership. Tweets contain only 140 characters but a picture paints a thousand words. ${ }^{27}$

First of all, it is important to note that many of the tweets in the list are tweeted by celebrities within the millennial generation, sometimes only by the inclusion of a Bible reference, and are often classic expressions of a therapeutic form of Christian spirituality known as moralistic therapeutic deism (MTD ). ${ }^{28}$ It is also important to note the different elements of the tweet - both textual and visual. So, Demi Lovato's tweet in position six includes only her avatar and the text "Jeremiah 29:11" (an archetypal millennial MTD text) and Cameron Dallas' tweet in position four includes his avatar and the text "Romans 8:18" accompanied by a smiling (flushed?) face emoji. ${ }^{29}$ In these tweets, the textual baggage of the tweet is minimal. It is perhaps assumed that the reader will know the text cited through their own devotional engagement with the Bible. This may well point to the tweeter's own devotional engagement as well. The addition of the emoji also enhances the tweet by adding some kind of emotional signature to the text - although this particular emoji is quite ambiguous.

Some tweets often contain a paraphrase of the text as well - so Dallas' other retweet in the list, referencing Psalms 16:11, contains a specific and rare translation of the verse, which is found only: in retweets of his original tweet of 2 Jun 2015; on a Dutch photoblog in Nov $2015^{30}$ since removed from public viewing; a now lost instagram on a teenager's site from Mexico; and by a tweet on 4 June 2015 from the Neesa Ratzenburg Foundation accompanied by hashtags about David and a picture of a rabbi - probably an unattributed and amended retweet of Dallas' tweet. ${ }^{31}$ It is probable that the verse arises from prosperity/ holiness spirituality, but the source is unknown. The paraphrase enables a specific emphasis to be placed on the tweet, which may well appeal to the tweeter

27 For a discussion of the role of tweets within digital religion, see Cheong, Pauline, "Twitter of Faith: Understanding Social Media Networking and Microblogging Rituals as Religious Practices", in: Digital Religion, Social Media and Culture: Perspectives, Practices and Futures, Cheong, Pauline, ed., Switzerland: Peter Lang, 2012, 191-206. Smith, Christian, Soul Searching: The Religious and Spiritual Lives of American Teenagers, UK: Oxford University Press, 2009.

29 Dallas has a very large Twitter following $(5.22 \mathrm{~m})$, his Vine account is the 11th most popular, and he has a further $8.1 \mathrm{~m}$ followers on Instagram.

$30 \quad$ No longer searchable.

31 The author has reached out to both Cameron Dallas and the Neesa Ratzenburg Foundation without success. 
or to the assumed cultural paradigms of the expected audience. In this instance, the text becomes more dominant than the visual - not least in the choice of specific paraphrase.

The second and seventh largest retweets (1 Cor 13:13 and Jn 1:5) were both sent from Ally Brooke Hernandez's account. Ally Brooke Hernandez is a member of a popular band Fifth Harmony. ${ }^{32}$ Both tweets include the text of the Bible verse and the citation. The tweet citing 1 Corinthians 13 also includes a heart emoji. Manny Pacquiao, a boxer well known for his political and social activism in the Philippines, tweets Psalm 120:1 in a similar format of Bible verse (reference and text, including capitalization of the divine name). Again, Tim Tebow, American football athlete renowned for being disciplined over painting Jn 3:16 on his face before a football match, cites Ephesians 4:32 with the full text of the Bible verse. These last three celebrity tweeters, Brooke, Pacquiao and Tebow provide normally unaccompanied verses and references in a style very close to or identical to that of verses shared from the major Bible websites and mobile applications - it is almost as if these verses are highlighted in and shared from a Bible app. The emphasis is much more on the text in these instances - as emphasized by the use of quotation marks. The only visual elements are the avatar and the use of the heart emoji in one of the tweets.

Siwon Choi, a devout Korean Christian and boyband member/moviestar, tweets a reference to a whole Bible chapter - "Colossians 3" - and accompanies this with a picture of himself riding a police motorcycle. The picture was taken as part of a film shoot for Dai Hup Guk - apparently the bike was towed by a special effects vehicle. ${ }^{33}$ But the connection with Colossians 3 seems tenuous - perhaps a reference to new clothes? The dominance and impact of the picture seems to affect the potential for retweeting here rather than the ambiguity of the Bible reference. Indeed, one might ask why the Bible reference is included at all, since it seems to bear little weight in this context. The Bible verse may well be being used as an evangelical hook - seeking to encourage Siwon Choi's fans to read the larger text? But the driver for this text is certainly the image rather than the text.

The top retweet (Phil 1:3) was originally tweeted from the account of a Philippine actress, best known for her viral Dubsmash video and now a successful television personality, Maine Mendoza. Mendoza has 3.3 million followers on Twitter. The (now deleted) tweet puts together a reference to Philippians 1:3 (no text) with a picture of Mendoza with fellow actor Alden Richards and the

$3^{2}<$ https://fifthharmony.com>, accessed 10.4.19.

33 <https://afspot.net/forum/topic/788138-choi-si-won-is-just-for-show-on-a-motorcycle/>, accessed 10.4.19. 
rather cryptic hashtag \#ALDUB5thMonthsary. The hashtag and picture refer to the hugely popular onscreen relationship between Mendoza and Richards ("Aldub"). If we therefore put together the different aspects of this tweet, we begin to see why it is so popular - a popular celebrity, playing a popular character, celebrating love, by using a Bible verse in a deeply biblical culture. However, the lack of a direct quotation undermines the Bible reference, makes some vague reference to a text which is assumed to be known by its intended audience. The reliance on visual culture suggests that people were retweeting the picture and its hashtag, and that the verse came along with it as a passenger, so as to speak, much like the previous tweet from Siwon Choi.

All of these tweets seem to reflect aspects of the personal faith response of celebrities to various contexts within societies favourably disposed towards the Bible. The number of retweets seems to be linked not to the specific Bible verses but to an image associated with the tweet, even if it is only the avatar of the celebrity, and the number of followers potentially willing to retweet the verse. Sometimes, especially with those celebrities seemingly tweeting from within Bible Apps, the text takes precedent. However, in other, not least in the last two, which are accompanied by pictures, the bible text seems to be a passive component, or a passenger, within a predominantly visual culture. The visual content in these dominates over the text and the texts ride undercover, perhaps cultural hints or markers.

Tweeting the Bible seems to be quite a popular form of engagement in contemporary American religious life. But here we see the difficulty of separating out textual messages from celebrity culture and visual imagery. One is left with the impression that fans tend to retweet because of the celebrity rather than because of the Bible verse quoted. Indeed, does the Bible verse add to the "squeaky clean" image of the celebrity and so add even greater appeal to their celebrity status? On the other hand, those texts which cite the Bible and which have little visual input also signal a different approach to celebrity tweeting potentially giving some perspective into the devotional life of the celebrity.

In a way, this is clearest in Rocchio's comments about the way that Pope Francis makes use of social media in order to show his own acknowledgement of contemporary culture. Rocchio talks of the Pope's humility in asking for prayer when he was revealed for the first time on the balcony overlooking St Peter's Basilica. One could call this an acceptance of contemporary culture signaled within a contemporary medium to show a shift away from stereotypical patterns of ecclesial domination. ${ }^{34}$ 
We have seen that celebrities make use of the Bible in different ways within their tweets - to connect more closely with various Biblically-aware cultures, to project a specific (Christian) morality to their readers, perhaps even to make use of their tweeting as a form of evangelism. In our final test case, we move to Hollywood and explore the adaptation of a Biblical story in Darren Aronofsky's Noah.

One of the potential problems of making a film out of the Noah story is not how much material there is but how little. Eight verses of historical background (Gen 6:1-7, 11-13), a few verses saying that Noah was a good man (Gen 5:30-32, Gen 6:8,9,22, Gen 7:1), a few to describe Noah's boat-building task (Gen 6:14-16) and the coming deluge (Gen 6:17, 7:4, 11-12, 17-20) with interspersed snippets of those to be saved - namely Noah's family (Gen 6:10, 18, 7:1, 13, 23) and the chosen fauna (Gen 6:19-20, 7:2-3, 8-9, 14-16). But none of these microthemes are developed in any detail. The three main strings of the narrative (warnings of impurity, a family to be saved and the animals) are wrapped around the ark and the impending doom - a bible story contorted within itself like a bowl of spaghetti.

But there is no rich sauce to accompany the convoluted pasta. Many details are missing: we just have scant measurements, numbers of animals, a family. There is no explanation of the boat-building task, sources for building supplies (how do you build a boat in a wilderness?), or the necessary provisions and technology; no exploration of theological nuance; no details to help make anything really understandable. Even going into other traditions, such as Noë's story in the Qu'ran (Suras 57, 11 and 23), offers little solid context to draw on apart from some speculation about Noah's lost son (Sura 11:42-46) and the suggestion that Noah grew his own trees! The rest depends on later speculation.

So much more detail has to be added for a blockbuster - certainly a blockbuster to fit our contemporary needs. Aronofsky's Noah is a proper, multimillion dollar, Hollywood blockbuster complete with special effects, blood and gore, even robot-like angels. It grossed $\$ 362 \mathrm{~m}$ dollars. ${ }^{35}$ To some extent the film seems to have more connection with post-apocalyptic thrillers than with Bible epics. Noah is a mean street fighter in a toxic, dying world, protecting his family and striving for what is right. The opening scenes have more in common with

35 For details of the film including plot synopsis, see IMDB: <http://www.imdb.com/title/ tt1959490/synopsis?ref_=tt_stry_pl $>$, accessed on 10.04.19. 
the Book of Eli or Mad Max. We are presented with a post-industrial world that faces imminent destruction because of the cost of unchecked technological development - a strange mix of technological urban culture vs environmental rural isolation. ${ }^{36}$ The ambiguity of a film set many years before industrialization but with industrial sites and processes at its heart allows the audience to find their own place in the film - the film draws them in and suggests that the narrative is not just a quaint stone age documentary.

Part of the ambiguity is also to pull away from the Biblical narrative. The film provides a kind of alternative space - neither the Bible we know, nor the Biblical tropes that we expect in a Biblical epic, and nor a deconstruction of those ${ }^{37}$ Instead, Aronofsky makes the decision to portray the 'nephilim' of Gen 6:4 in terms of the Watchers from the Enoch traditions, as fallen angels encrusted, imprisoned, by the very rocks of the earth, as pseudo-robotic allies and enemies at the same time - sometimes pet-like in their support, at others, formidable fighting machines. In creating what he called the least biblical film ever, Aronofsky takes Lamech's son, the maker of tools in bronze and iron, Tubal Cain (Gen 4:22) as a foil, or a counterpart for Noah. Tubal Cain represents the chaotic, industrial, brutish, worldly antithesis to Noah's ascetic, environmental, family-orientated goodness. Cain fights, builds, rules, slaughters; he embodies the very horror of the world which Yahweh has determined must end. But gradually through the film, Aronofsky forces the viewer to ask whether this antithesis is real. Both men are seeking to save their own people. Both men are horrified by God's silence. Both men are seeking both justice and mercy. Indeed, in the second half of the film, as we move from the expansive terrain below Methuselah's mountain to the claustrophobic confines of the Ark, Noah seems to become more and more like his mortal enemy - technologized, isolated, bent on destruction as he creates his own forge in the heart of the ark: his murderous intent becomes the exact opposite of a 'good man'. Indeed, we have already seen Noah's tendency for irrational behaviour in his decision to go through the industrial zone at the beginning of the journey - a decision which allows them to find Ila (one of the key characters of the film who married Shem and has twin children, who are threatened by Noah's violence) but which almost leads the family into destruction first at the hand of strangers and then at the whim of the Watchers. ${ }^{38}$

Noah has to face his own demons and come to terms with his own monstrosity - indeed even towards the end of the film, he remains convinced that

36 Rocchio also provides a detailed narratological analysis of the film: Culture Machine, $3^{6-}$ 46.

37 Rocchio, Vincent, Culture Machine, 38; 43.

38 Rocchio, Vincent, Culture Machine, 39. 
he has failed God. The solution comes not by an appeal to Noah's fundamentalism, nor through the brutality of industrialization but rather through the wisdom and grace of Naameh, Noah's wife, and Ila, Noah's daughter-in-law. Both women offer a wisdom which Noah ultimately cannot ignore and which for the viewer "constructs a rift between secular humanism and its most vociferous opponent in contemporary American culture: Christian fundamentalism."39 Rather than the Bible epic pivot between the two, like The Last Temptation of Christ or The Passion of the Christ, this Bible epic chooses to create a via media, a choice for wisdom and collaboration and creativity rather than for destruction. There is a definite transformative aesthetic at the heart of the production.

To some extent, what Aronofsky seems to be doing is a classical way of engaging with the Biblical text - he's creating a midrash, or an interpretative reading of the text. Aronofsky believes that at the heart of the Noah story is an unsolved question about justice and mercy. How does a God who wishes to destroy all creation, to start again, not decide to destroy all humanity and create a world without human beings at all? Indeed, Noah argues himself into exactly the latter position and seeks to destroy his own family. Naameh and Ila persuade him, eventually, that this is not God's purpose. In the end, Noah chose to save the lives of Ila's children, "You chose love", she says. ${ }^{40}$ After exploring Genesis, Jubilees, Enoch and the Zohar, after a creative process of moulding the traditions together and finding a synthesis between text and imagination, Aronofsky declares his Noah to be an exercise in midrash: "the text exists and is truth and the word and the final authority. But how you decide to interpret it, you can open up your imagination to be inspired by it."41

What lies at the heart of Aronofsky's midrash, Aronofsky's Noah, is the exploration of hamas (destruction/separation) - the hamas of Tubal Cain's industrial brutality, the hamas of Noah the radicalized loner, the hamas which the Creator inflicts upon his own creation in response. But that hamas is reinterpretated by Naameh and Ila in terms of God's wider provision for love. Hamas is the preferred route for the men (perhaps representing Western culture's expressions of both secular humanism and fundamentalism). On the other hand, the women represent an alternative path of community integration, of social creativity, of embodied love, in stark contrast to the men (reflecting contemporary communitarian approaches to social integration and inclusion). As such, the film's characters offer a biblical reinterpretation of

39 Rocchio, Vincent, Culture Machine, 41.

40 Rocchio, Vincent, Culture Machine, 44.

41 Darren Aronofsky quoted in Peter Chattaway's “The Genesis of 'Noah', Christianity Today, March 272014 [web article], available at: <https://www.christianitytoday.com/ct/2014/ march-web-only/genesis-of-noah.html $>$, accessed 10.4.19. 
contemporary cultural divides which have become even more extreme since the film's release.

The film arrives at this point by debunking many of the accepted ways which Hollywood deals with Bible epics. Moreover, Aronofsky makes use of many different tools to make clear his aim to think theologically though the issues rather than just carry on with the normal visual and materials forms expected in the medium. Whether the film was a success is therefore immaterial since the work it was doing was to break a pattern of how to deal with the Bible on screen rather than to retell the Noah story. ${ }^{42}$

The three examples furnish us with different images of the Bible's encounter with visual culture, or the existence of the mediated Bible in contemporary culture.

In one of them, the text succumbs to the dominance of visual/material culture. At the same time, the text underwrites what happens in the Bible's mediated form. The glory of the Gospels creates a sumptuous Insular illuminated manuscript. But at the same time, the audience's lack of familiarity with the text and the languages in which it is written means that the text is uncoded, illegible, latent. What we know of the text and its importance has to be gleaned from the visual and material culture, which the text then rides as a passenger. In the context of the Lindisfarne Gospels, the text rides in a sumptuous vehicle and we, the audience, cannot but note its power and importance.

Tweets are a much more humble form of transport. But the tweets are also much more diverse. Sometimes the Bible rides along with the celebrities, ambiguously part of their cultural appeal, perhaps part of their media messaging to their audience. Sometimes, the Bible eclipses the celebrity fully quoted and cited and perhaps even "emoji-ed". But even here, the Bible is dependant on the celebrity transport. The celebrity is doing the tweeting and it is much more likely that the fans are retweeting the messenger rather than the message. And in others, the Bible seems to act as a footnote, an evangelistic hook perhaps, an addendum to visual culture. I am intrigued that both of the tweets where pictures dominate are from Asian TV/Movie stars. Here, the tweets are conveying imagery first and foremost and the Bible references seem to be a sideline to the main message - virtue signaling perhaps? 
Although Aronofsky aimed to create the most unbiblical epic ever, he seems to have created a theologically rich form of midrash. Of all of the examples, this is the most visual, the most culturally engaged exploration of the visual text. It is a bit like the Lindisfarne Gospels but also different from them. Both the Gospels and Aldred's gloss seem to be part of the power dynamics of the Church/State in early medieval Britain. Both point to the power of the text and the need for a fledgling state to draw upon that power, to appropriate its power. But Noah rejects former norms and the potential powers-that-be in our contemporary world and seeks to develop a via media through social constructivism. In this the Biblical text, scant as it may be, plays a full part. And indeed it may well play a fuller part because of its own fragility. The text is able to be developed and explored and queried in order to set up a transformational alternative to both historical and contemporary issues. This example undertakes some serious theological heavy lifting and apparently succeeds.

Indeed, contrary to the suggestion in the title of this paper, visual culture seems to magnify the voice of the text rather than to minimize it. In each of the examples, we see a kind of symbiosis between the Biblical text and visual culture in which each seeks strength from the other, and each seeks to make its communicative task complete through the other.

Of course, that could just be a reflection of the examples I have chosen. There are other ways in which visual culture queries, contests, and challenges the text. But perhaps even there, the appropriation of the biblical text into visual culture is yet another form of enhancement rather than negation. Katie Edwards has proposed that we need to be less anxious about the warnings of decreasing biblical literacy in Western culture ${ }^{43}$ and instead notes that "biblical stories are woven into the very fabric of contemporary culture". ${ }^{44}$ We should, she suggests, be discussing the "ubiquity of the bible in popular culture and its impact on biblical literacy". 45 The questions raised by this paper relate to the meaning and effect of what Edwards calls the Bible's ubiquity in contemporary culture. Our tentative findings point to the power of a fragile text to maximize its presence within visual culture and continue to transmit its message. The Bible remains as a mediated text and able to maintains its identity as such even within a culture where a picture can paint a thousand words.

43 pace Field, Clive, "Is the Bible Becoming a Closed Book? British Opinion Poll Evidence" Journal of Contemporary Religion 29.3, 2014, 503-528, and then many other polls arguing for a decline in biblical literacy in the West.

44 Edwards, Katie, Rethinking, ix-x.

45 Edwards, Katie, Rethinking, $\mathrm{x}$. 


\section{References}

Brant, Jo-Ann, Dialogue and Drama: Elements of Greek Tragedy in the Fourth Gospel, USA: Hendrickson, 2004.

Chattaway, Peter, “The Genesis of 'Noah”, Christianity Today, March 272014 [web article], <https://www.christianitytoday.com/ct/2014/march-web-only/genesis-of-no ah.html $>$.

Cheong, Pauline, "Twitter of Faith: Understanding Social Media Networking and Microblogging Rituals as Religious Practices", in: Digital Religion, Social Media and Culture: Perspectives, Practices and Futures, Cheong, Pauline, ed., Switzerland: Peter Lang, 2012, 191-206.

Derrida, Jacques, L’Animal que donc je suis, Paris: Éditions Galilée, 2006.

Derrida, Jacques, Of Grammatology, trans. Spivak, Gayatri Chakravorty, UsA: The John Hopkins University Press, 1976, 158-159.

Edwards, Katie, Rethinking Biblical Literacy, u K: Bloomsbury, 2015.

Field, Clive, "Is the Bible Becoming a Closed Book? British Opinion Poll Evidence" Journal of Contemporary Religion 29.3, 2014, 503-528.

Grønstad, Asbjørn, Vågnes, Øyvind, "What do pictures want? An interview with W.J.T. Mitchell" Images: Journal for Visual Studies, accessed 12.7.2016: <http://www.visualstudies.com/interviews/mitchell.html>.

Mitchell, W.J.T., "Showing seeing: a critique of visual culture", Journal of Visual Culture, Vol. 1(2), 2002, 166.

Morgan, David, The Embodied Eye, Religious Visual Culture and the Social Life of Feeling, USA: University of California Press, 2012, xiii.

Morgan, David, The Sacred Gaze: Religious Visual Culture in Theory and Practice, UsA: University of California Press, 2005.

Poleg, Eyal, Approaching the Bible in Medieval England, uK: Manchester University Press, 2013.

Purgar, Krešimir "Visual Studies and the Pictorial Turn: Twenty Years Later", Images No.2, 2014, accessed 12.7.2016: <http://www.visual-studies.com/images/no2/purgar. html>.

Rocchio, Vincent, Christianity and the Culture Machine, Eugene: Cascade Books, 2016.

Smith, Christian, Soul Searching: The Religious and Spiritual Lives of American Teenagers, Uk: Oxford University Press, 2009.

Stanton, Robert, The Culture of Translation in Anglo-Saxon England, Boydell and Brewer, 2002.

Wright, Brian J., "Ancient Literacy in New Testament Research: Incorporating a few more line of enquiry", Trinity Journal 36, 2015, 161-189. 


\section{List of Internet Ressources}

<http://www.bbc.co.uk/news/uk-england-tyne-24329431>, accessed 10.4.19.

$<$ https://www.bl.uk/collection-items/lindisfarne-gospels>, accessed 10.4.19.

$<$ https://www.dur.ac.uk/palace.green/whatson/details/?id=18081 >, accessed 10.4.19.

$<$ http://www.bl.uk/onlinegallery/ttp/lindisfarne/accessible/introduction.html>, accessed 10.4.19.

<https://www.openbible.info/blog/2015/12/the-bible-on-twitter-in-2015/>, accessed 10.4.19.

$<$ https://fifthharmony.com>, accessed 10.4.19.

$<$ https://afspot.net/forum/topic/788138-choi-si-won-is-just-for-show-on-a-motorcy cle/>, accessed 10.4.19. 